\title{
Female Choruses and Gardens of Nymphs: Visualizing Chorality in Sappho*
}

\author{
Katerina Ladianou
}

In light of Romanticism, Sappho's poetry has been read as an expression of the poet's inner feelings. According to this model, Sappho is a soloist, performing her songs and playing her lyre in a private space, a small circle of same-sex companions. ${ }^{1}$ This idea went unchallenged until fairly recently, but the similarity of Sappho's songs to Alcman's Partheneia and the rise of performance studies - especially since the publication of Calame's groundbreaking book ${ }^{2}$ have cleared the way for discussions of Sappho's public persona and the possibility of choral, public performance. Although it is now acknowledged that at least some of Sappho's songs were probably meant to be performed chorally, nevertheless it is true that the extended fragments of Sappho provide us only with descriptions of choral activity, not explicit stage directions that would directly point to their performance.

Adding to this ongoing discussion, this chapter will first focus on the imagery and visualization of chorality. I will show how the visual blends with other senses in Sappho's fragments in an attempt to map out the synaesthetic quality of Sappho's poetry. In the second section of this paper, I will use later references to Sapphic poetry in an attempt to show that synaesthesia was considered

* I would like to thank R. Martin, A. Lardinois and A.E. Peponi for organizing a stimulating conference, the anonymous readers for their detailed and helpful comments, Zacharoula Petraki for reading many drafts and enduring long discussions, Heidi Broome-Raines for meticulous editing. Finally, I am grateful to Anastasia-Erasmia Peponi for my first inspirational look at lyric.

1 Gentili (1988). Winkler (1990); Hallett (1979) discuss Sappho's social context and the coexistence of public and private in the Sapphic corpus. Parker (1993) re-examines testimonia supporting a sympotic performance by older women. Calame (1996), (2001) discusses choral performance within an initiatory context. For Nagy (2007), Alcaeus and Sappho songs were performed by choruses of young men and women in ritual contexts. Lardinois (1994), (1996), (2001) also argues in favor of public choral performance even in the case of so-called 'solo' songs such as frr. 94 and $96 \mathrm{v}$.

2 Calame (2001).

(C) KATERINA LADIANOU, 2016 | DOI: 10.1163/9789004314849_015

This is an open access chapter distributed under the terms of the Creative Commons Attribution-

Noncommercial 3.o Unported (CC-BY-NC 3.0) License. 
an inherent characteristic of this poetry. Taking Philostratus Imagines 2.1 as a starting point, I will further refer to Aulus Gellius and an epigram from the Palatine Anthology to show that later authors' reception of Sappho's poetry points both to a plurality of voices and to a blurring of the senses as main characteristics of her poetic art. Furthermore, it will be argued that this blurring of senses is related to these authors' understanding of Sappho's poetry as essentially choral. Finally, I will come back to Sappho's poems to demonstrate how the plurality of voices and multiple sensibilia assumed by the later authors can be found in her poetry. In conclusion, a question will be raised: is it possible to argue that the visual and the blurring of the senses in Sappho could be an added argument for the choral dimension of her poetry?

\section{The Look of Song: Sappho and the Visual}

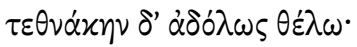

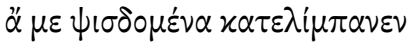

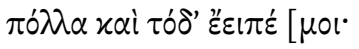

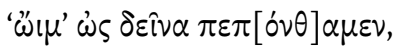

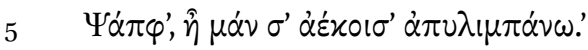

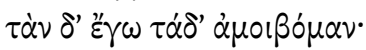

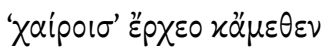

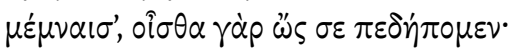

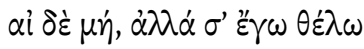

10

${ }^{\prime \prime} \mu \nu \alpha \operatorname{lo\alpha l}[\ldots ..] \cdot[\ldots] . . \alpha \mathrm{l}$

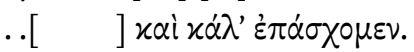

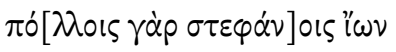

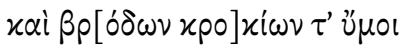

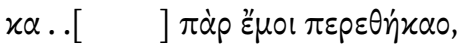

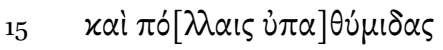

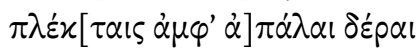

$\dot{\alpha} \nu \theta \dot{\varepsilon} \omega \nu \stackrel{\varepsilon}{\varepsilon}[\beta \alpha \lambda \varepsilon \varsigma] \pi \varepsilon \pi 0 \eta \mu \mu \varepsilon \dot{v} \alpha \alpha \varsigma$,

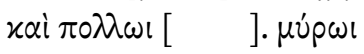

$\beta \rho \varepsilon v \theta \varepsilon i \omega l[\quad] \rho v[..] \nu$

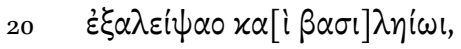

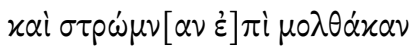

$\dot{\alpha} \pi \dot{\alpha} \lambda \alpha \nu \pi \alpha .[\quad] \ldots \omega \nu$

ह่'ंins $\pi \dot{\theta} \theta 0[\nu] . \nu i \delta \omega \nu$,

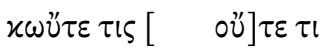

25 îpov oủdv[ 


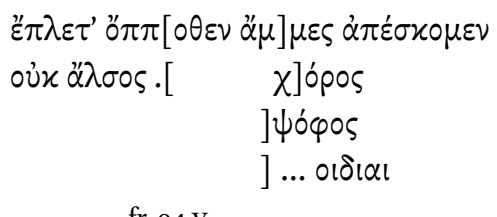

Honestly, I wish I were dead. She was leaving me, shedding many tears, and saying this: 'Alas, what a dreadful thing has happened to us, Sappho, I am leaving you, honestly, not by my own will.'

And I replied to her thus: 'Go, farewell and remember me, for you know how we cherished you. And, if you don't, I wish to remind you ... that beautiful things happened to us. Many garlands of violets and roses and saffron you put around you, lying close to me, and round your tender neck you put woven garlands made from flowers, and much perfume ... made from flowers ... royal ... you anointed yourself, and lying on the soft couch you used to satisfy the desire ... there was neither ... nor a shrine ... from which we were absent ... nor grove ... dance ... sound ... songs. ${ }^{3}$

As the beginning of fr. $94 \mathrm{~V}$. is missing, there is no clear indication either of the identity of the speaking 'I' or of the time of utterance, both of which have been the object of scholarly debate. ${ }^{4}$ I am inclined to think that this fragment evokes various moments in time: the beginning of the fragment stages the lyric self at a present moment of distress ( $\theta \dot{\varepsilon} \lambda \omega$, 'I wish I were dead', 1 ) and this is followed by a shift to the past moment of separation ('she was leaving me, shedding tears', $x \alpha \tau \varepsilon \lambda(\mu \pi \alpha v \varepsilon v, 2)$. There follows a dialogue set in the past: she

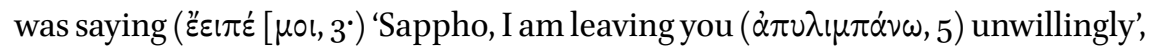

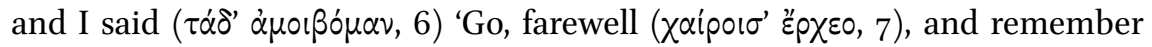
me $\left(\chi \alpha \ddot{\mu} \mu \varepsilon \theta \varepsilon v / \mu \varepsilon \dot{\varepsilon} \mu \nu \alpha \sigma^{\prime}, 8\right)$ '. A second person emerges as an interlocutor who is addressing by name the lyric ' $\mathrm{I}$ ' ( $\Psi^{\prime} \alpha \varphi^{\prime}$ ', 5). Then there is another time shift, as memory helps both the speaking 'I' and the audience to return again to the past, even before the separation: 'remember how we lived together, and if you don't, I wish to remind you ( $\left(\theta^{\prime} \lambda \omega \mid\right.$ / oै $\left.\mu \nu \alpha \iota \sigma \alpha l, 9-10\right)$ '. Although this is a

3 For all Sappho's fragments, with the exception of the Tithonus poem, I cite Campbell (1982). Translations, unless otherwise indicated, are mine reflecting the discussion at hand. Words not fully attested in the Greek text are marked with a question mark.

4 For an overview of past scholarship see Burnett (1983) 292-293 and esp. n. 38; Greene (1996). In short, scholars attribute the first line to (a) Sappho's addressee at the time of parting, (b) the female narrator of the parting scene, (c) speaking Sappho at the time of parting. 
narration of the past, there is a sense of the future. ${ }^{5}$ The lyric 'I' will go on to recall the previous experience of their common life, trying to preserve, store, and secure the memory of the past. The self, then, is preserved as past and future combined. Memory is both "what we were" and "what we will have been". What the speaker wants is both to create a memory and to share it to ensure its preservation in the future. Three different voices are then staged in a dialogue which takes place across several spatial as well as temporal positions. ${ }^{6}$

The opening of the fragment, according to this reading, is the space of the here and now, only described via the feelings of despair of the speaking person, that swifty changes into the space of separation, the final dialogue. Here the dialogic 'space' is set between the 'I' and the 'you', with the 'I' named by her interlocutor, a signature Sapphic trick. In at least 19 of its 29 preserved lines, then, the poem focuses on the memory of the past, in a last desperate attempt to preserve through memory a eutopia of togetherness. Furthermore, the construction through memory of the eutopic space focuses on its visualization: the

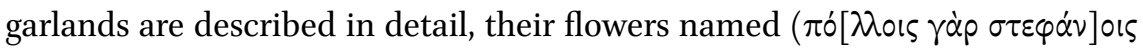

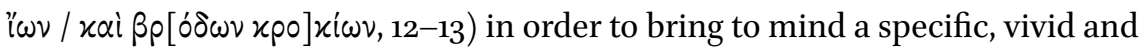
multicolored picture. The description of the performative reality is not only visualized but also described synaesthetically, since all senses are activated and addressed. It is not only the garland but the act of self- and mutual garlanding

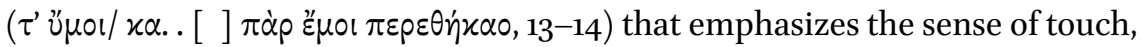
highlighted by the adjectives $\dot{\alpha}] \pi \dot{\alpha} \lambda \alpha \mathrm{l}$ (16), $\dot{\alpha} \pi \dot{\alpha} \lambda \alpha \nu$ (22), $\mu 0 \lambda \theta \dot{\alpha} x \alpha \nu$ (21) in combination with the verbs $\ddot{\varepsilon}[\beta \alpha \lambda \varepsilon \varsigma]$ (17) and $\xi^{\prime} \xi \alpha \lambda \varepsilon$ í $\psi \alpha 0$ (20). Smell is also a part of the description: the adjectives $\beta \rho \varepsilon \dot{v} \theta \varepsilon \varepsilon \omega l$ (19) and $\beta \alpha \sigma l] \lambda \eta^{\prime}(\omega l$ (20) modify the noun $\mu v \dot{p} \omega \mathrm{\omega}(18)$ probably describing a specific smell. Finally the sense of hearing is also described in the last, regrettably fragmentary, lines. Although the lines are broken, the word $\chi$ ]ópos (27) is highly probable, and the more difficult read-

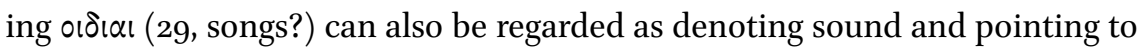
performance. ${ }^{7}$ Finally the term yópos (sound) points not only to the sense of hearing but also to a lyric performance, since it can refer to the sound of musical instruments (usually the flute or lyre). ${ }^{8}$

$5 \Theta \varepsilon \dot{\varepsilon} \omega \partial^{\circ} \mu \nu \alpha \iota \sigma \alpha l$ is not a future per se but a future expression, a wished-for-event situated in the future.

6 For the polyphonic dimensions of the poem see also Yatromanolakis (2003) 55-56. He also speaks of 'dreamlike images deprived of specific time' (57).

7 As Lardinois (1996) 163-164 points out, 'the whole poem ... is concerned with choral performances'.

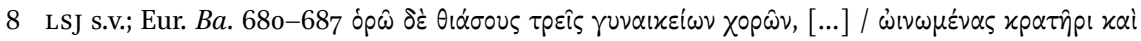


It is evident, then, that Sappho stages a female eutopia through the description of female singing, the sound of multiple female voices, smells, and textures. Almost all the senses come into play and lines 21-23 explicitly describe the inti-

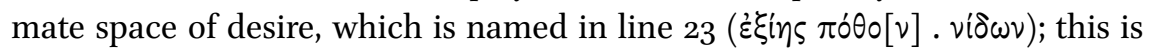
an explicit scene of female homoerotic desire as a marker, I suggest, of female homilia. Sappho's description emphasizes the body and its movements: the soft neck on which the garlands are placed, the bodies anointed with perfumes, the bodies reclining on couches feeling soft to the touch. Female desire is heavily emphasized, as it is also in Alcman's Partheneia. Most importantly, in the broken end of the fragment there is the memory of women singing and probably dancing. ${ }^{9}$

I hope to have shown that fr. $94 \mathrm{~V}$. is set in a fluid time and space that is represented as such through a fusion of voices (by switching grammatical persons) and senses. In fr. $44 \mathrm{~V}$. we find another case of visualized fusion of song and dance. I believe that this fragment can be compared with fr. 94, to throw some light on the ending of the latter. Fragment 44, as we have it today, begins with a vivid description of the wedding procession of Hector and Andromache as narrated by the herald Idaeus:

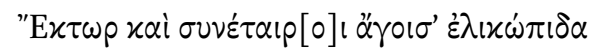

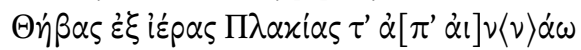

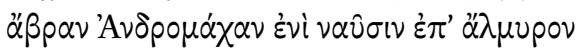

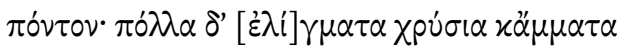

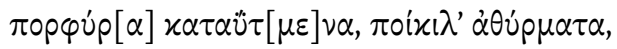

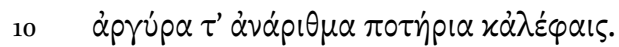

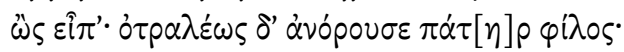

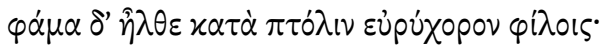

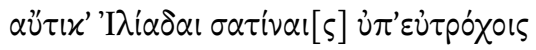

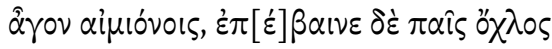

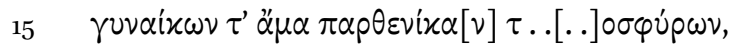

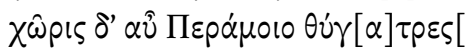

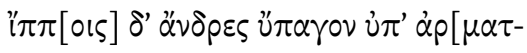

fr. $44 \cdot 5^{-17} \mathrm{~V}$.

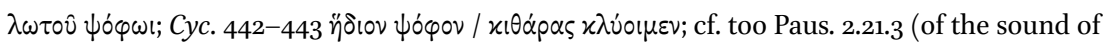
the trumpet).

9 At least according to Lobel-Page who read $\chi$ ]opós where Voigt prints].pós. See Lardinois (1994) 70 and n. 50 . 
... Hector and his companions are bringing the lively-eyed, graceful Andromache from holy Thebe and ever-flowing Placia in their ships over the salt sea. And there are many golden bracelets and perfumed purple robes, ornate trinkets and countless silver drinking cups." So he spoke; and nimbly his dear father leapt up, and the news went to his friends throughout the spacious city. At once the sons of Ilus yoked the mules to the smooth running carriages, and the whole crowd of women and tenderankled maidens climbed on board. Apart drove the daughters of Priam ... and unmarried men yoked horses to chariots ... ${ }^{10}$

The herald's words imply an internal audience: the Trojans, to whom the speech is addressed. Although this is a description spoken out loud by the herald and is therefore directed at the sense of hearing his words create a vivid visual image. First, the long journey from Thebes and Placia to Troy across the sea is conjured up for the audience's eyes. Then Andromache is described; the lively look in her eyes travels with her from line 5 to line 7 , where it meets the noun it qualifies, as the journey is structurally placed between the adjective and the proper name. The emphasis on Andromache's glance creates the impression that the journey is seen through her own eyes. Then the catalogue of the wedding gifts is presented with an emphasis on the costliness of materials. Gold, silver, ivory,

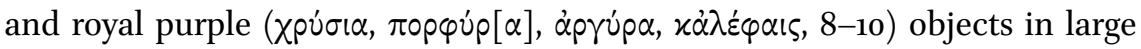
quantities $(\pi \dot{o} \lambda \lambda \alpha, \dot{\alpha} \nu \dot{\alpha} p \mid \theta \mu \alpha, 8,10)$ create an atmosphere of luxury and a colorful and bright visual image. The end of Idaeus' message is immediately followed by the reaction of the Trojan royal family, who with the Trojan people comprise the poem's internal audience, to the news. The message is first conveyed to Priam, who leaps up from his throne, then it travels all over the city. The spaciousness of the city is emphasized both verbally (evंpúxopov) and through the description of the crowd as it prepares to meet the royal couple. The reference to the preparations of the father and friends, then of the children, young women, and daughters of Priam, and finally of the young and grown men, proceeds gradually from the confined space of the palace to the open space of the city streets, aptly showing the engagement of the whole polis both as a space and as a citizen body.

The action of the rest of the fragment takes place in the civic space, and the emphasis rests on the description of various lyric performances as visualized for an external audience: 


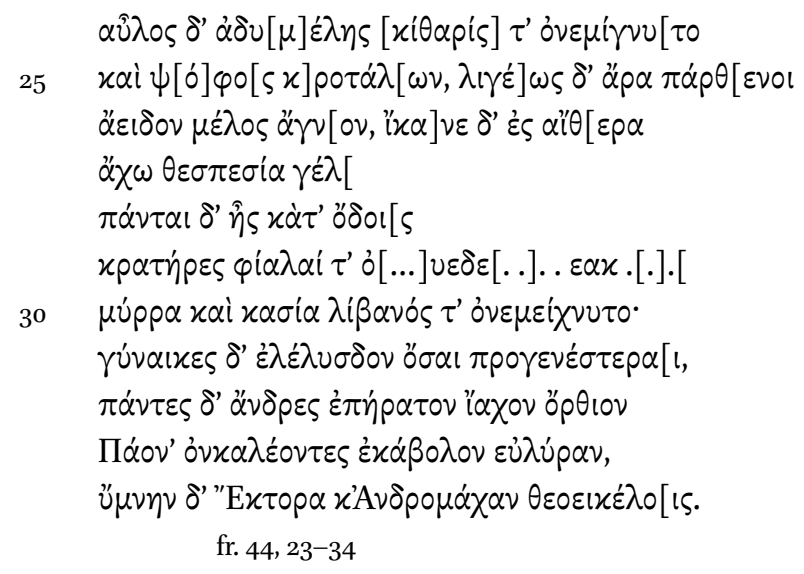

The sweet-sounding pipe mingled with the lyre and the sound of the castanets, and maidens sang clearly a holy song, and the exquisite echo reached the sky ... and everywhere in the streets ... bowls and cups ... and cassia and myrrh and frankincense were mingled. And the older women cried out and all men raised a loud cry calling on Apollo Paean, the Archer, the player of the lyre, praising Hector and Andromache, similar to gods.

The citizen body, previously described on the way to meet the royal couple, is now presented in performance. The choruses are shown in action in the order employed previously to describe the preparations. There are probably

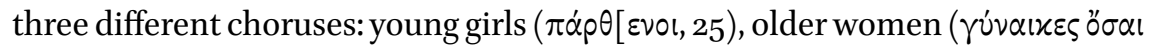

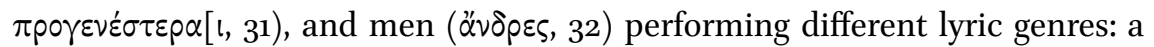

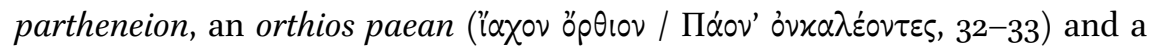

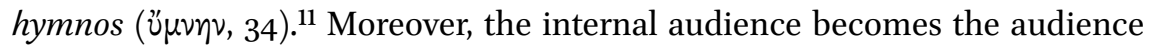
of the festivities, but Hector and Andromache-previously the topic of the herald's message - can be seen as part of the internal audience since they now

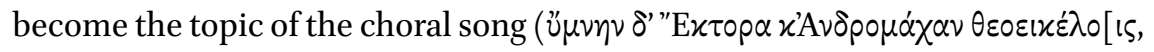
34).

The external audience, for whom the vivid description is intended, is led to perceive the performances through all senses. The fragment describes choral

11 See Carey (2009) for an overview of past scholarship and an excellent introduction to lyric genre categories. With most scholars Carey emphasizes the resistance of lyric genres to rigid categorization, pointing out that 'literary genres are best seen not as categories but as tendencies' (22). Be that as it may, I do not intend here to make any suggestion regarding the content or categorization of specific lyric genres. What I am pointing out is that the text refers explicitly to recognizable lyric genres, such as a hymn and orthios paean. 
performances and, just as in fr. 94, in fr. $44 \mathrm{~V}$. the visual element is combined not only with sound but also with smell. There is the sound of pipes ( $\alpha \hat{v} \lambda \circ s$ $\left.\delta^{\prime} \dot{\alpha} \delta \cup[\mu] \dot{\varepsilon} \lambda \eta \varsigma, 24\right)$, castanets ( $\psi[\dot{o}] \varphi \circ[\varsigma x] \rho \circ \tau \dot{\lambda} \lambda[\omega \nu, 25)$, and songs ( $\alpha^{\prime \prime} \chi \omega \theta \varepsilon \sigma \pi \varepsilon-$

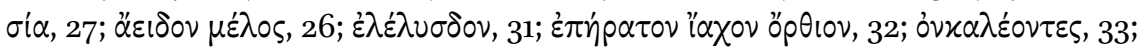
ن $\mu \nu \eta \nu$, 34) performed by men and women. Indeed, the senses seem to be mingled: the description of sound is brought together with the description of scent

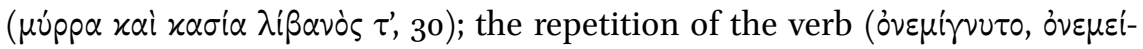
$\chi \vee v \tau 0,24,30)$ emphasizes the fusion, connecting it with choral performance. Finally, when the crowd mingles, women and men sing together and even the wine is mixed in the mixing bowls. Apollo is called in their song by many of his epithets: he is Paean, archer, and lyre-player. Lyric genres are fused. In this ecstatic description of a wedding ceremony, nothing is static, nothing is separate; everything is mobile and fused together literally and metaphorically. The fragment sets up different audiences, viewers and spectacles, but this categorization is fluid as well: the internal audience of the herald's message becomes the audience or the performers of the celebratory choral dances. Andromache, a viewer in the beginning of the poem, becomes a spectacle, the subject of performance and its audience at the same time.

The fusion of the senses is connected to the description of choral performances also in fr. $2 \mathrm{~V}$. Already Hermogenes in his second-century AD treatise On the Kinds of Style noted that the pleasure derived from this fragment has to do with the visualization of the locus amoenus. Quoting fr. 2 he argues that certain things can afford pleasure ( $\dot{\delta} \delta \circ v \eta$ ) not only to the eye when seen but

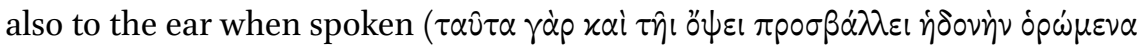

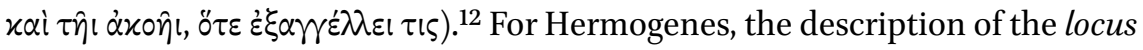
amoenus targets both the eye and the ear: by visualizing the beautiful place, the picture is set before the eyes of the audience while listening to the poem. At the same time the description engages the ear as well, not only because the performance of the poem is intended to be heard but also because the description is not only visual but also acoustic.

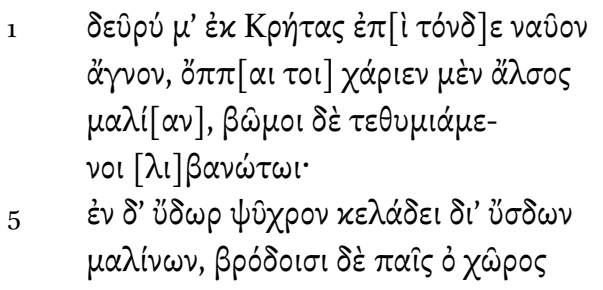




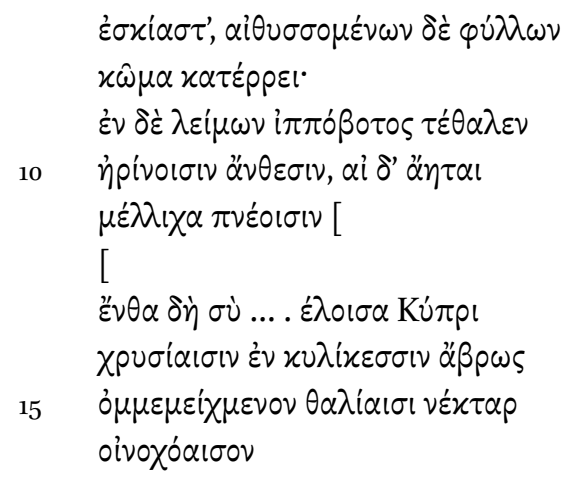

Hither from Crete to this holy temple (?) where is a delightful grove of apple trees and altars smoking with incense. There, your cold water resounds while rushing through the apple branches, and the whole place is shadowed by roses, and from the shimmering leaves sleep ... down (?) There is also a meadow, grazed by horses, blossoms with spring flowers, and the breeze sweetly blows. There you ... taking, Cypris, charmingly pour in golden cups nectar mingled with our festivities.

The space is carefully constructed by the use of deictic markers: the second person invocation to Cypris stages a dialogue between the persona loquens $(\mu \varepsilon, 1)$ and a persona audiens $(\sigma \dot{v})$ that is set in two different spaces. Cypris

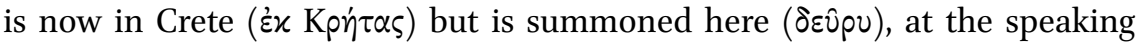
position of the speaking 'I' which is first defined by means of deictic markers

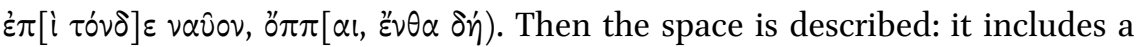
temple ( $\nu \alpha \hat{v} \circ \nu$ / $\alpha$ r $\gamma \circ \nu)$, a grove with apple trees ( $\alpha \lambda \sigma \circ \varsigma / \mu \alpha \lambda i[\alpha \nu, 2-3)$, an altar

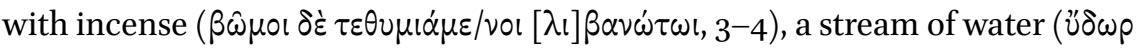

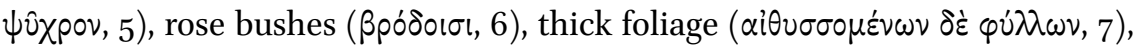

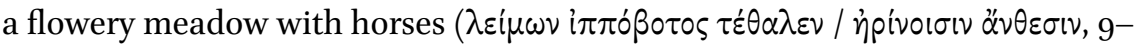
10)..$^{13}$

The grove is probably not inhabited since and there is no description of human presence. The smoking altar, however, denotes human activity and the end of the poem suggests a gathering $(\theta \alpha \lambda i \alpha \iota \sigma l, 15)$ where Cypris is invited as a wine bearer (oivoxóaloov, 16). In addition to the goddess, a second internal, now mortal, audience emerges: the members of the $\theta \alpha \lambda i \alpha$. Although there is no description or invocation to the mortal audience, the grove is described

13 Most editors accept the emendation vavoov. Contra Yatromanolakis (2003) 54-55 who reads

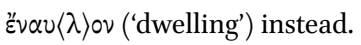


through the totality of human senses creating such a presence. Smell, touch, and hearing are also employed: the smell of the incense, the cold water, the sound of water, the sleep all presuppose a human presence. The description is also mobile: the altar is smoking, the water is running, the breeze is blowing, sleep is coming down. According to Hermogenes, such a setting gives pleasure to both the viewer and the listener; hence it can be suggested that the description constructs an internal audience for the performance by describing how the pleasurable setting impacts their senses.

Although the descriptive context can sometimes be identified with its performative context, I only submit that fragment as good evidence that the fusion of the senses is connected to the description of choral performances. Moreover, it is noteworthy that the representation of a choral performance emphasizes fusion of senses as its indispensable characteristic in the context of Sapphic poetry. In the following section, I will show that this is the case for later contexts as well.

\section{Looking at Sappho's Songs: Philostratus 2.1}

In my discussion of the importance of the element of visualization to Sapphic poetry, I hope to have shown that the visual is often connected with the other senses, creating a synaesthetic, pleasurable, vivid image, one that Hermogenes would call hedonic. It is interesting, then, that such an emphasis on visualization is evident in the later reception of Sappho. In this section, I will first discuss Philostratus Imagines 2.1 and later bring in Aulus Gellius and an epigram from the Palatine Anthology in an attempt to show that visualization and the blurring of the senses was considered by them an indispensable characteristic of Sapphic poetry. Secondly, I will go on to argue that in the mind of later audiences such a synaesthetic visual effect was closely connected with choral performance.

Philostratus' Imagines, a collection of ekphraseis of the paintings thataccording to the narrator-decorated a gallery in Naples, is the obvious place where literature and representational art meet. ${ }^{14}$ One of the paintings

14 The bibliography on ekphrasis is vast and exploring it is not within the scope of this paper. For an introduction and extended bibliography see Leach (1988); Fowler (1991); Goldhill (1994); Bartsch and Elsner (eds) (2007). On ekphraseis in Philostratus' Imagines see Shaffer (1998) and Dubel (2009). Most recently, Whitmarsh (2013) has discussed artwork in erotic contexts, raising questions on gender politics. 
depicts Sappho and a group of young girls in a ritual setting. The passage is worth quoting in full: ${ }^{15}$

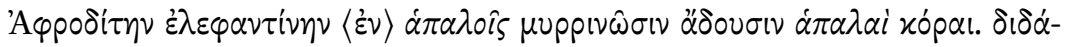

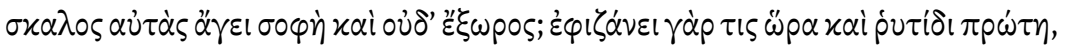

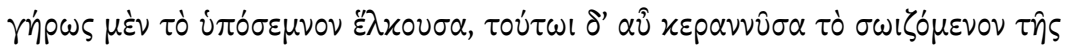

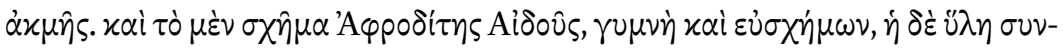

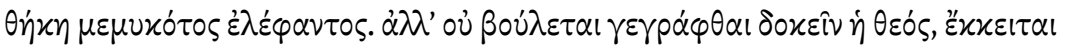

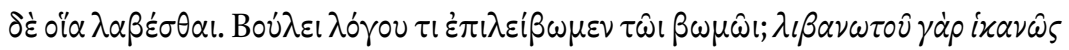

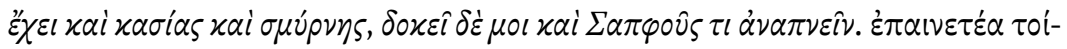

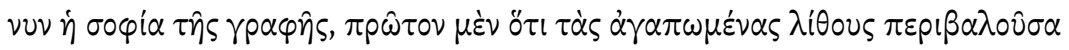

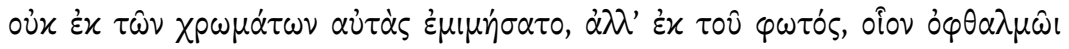

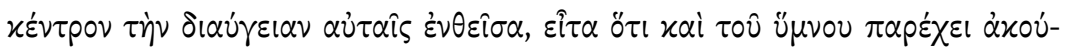

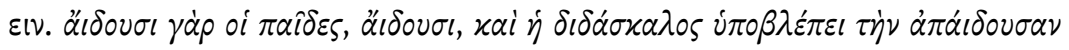

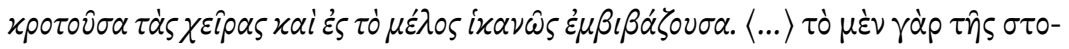

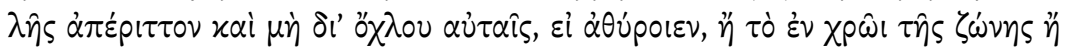

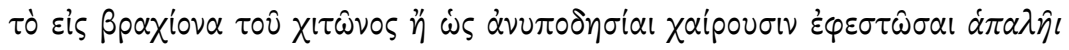

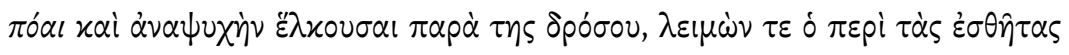

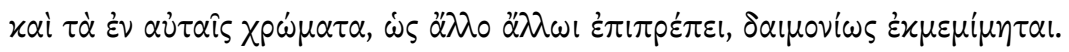

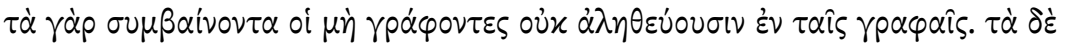

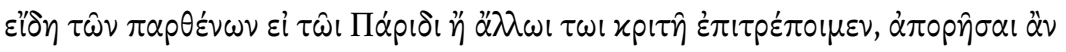

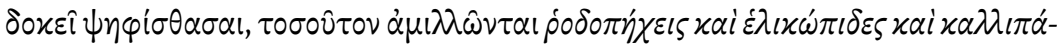

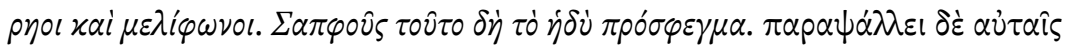

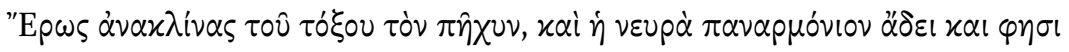

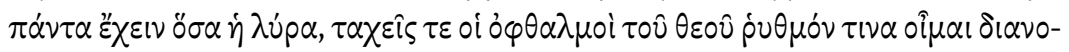

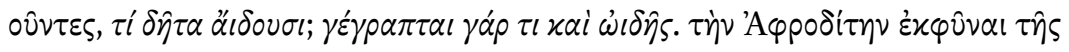

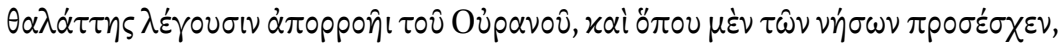

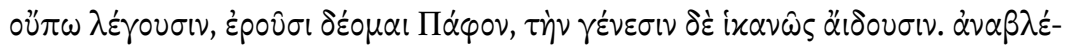

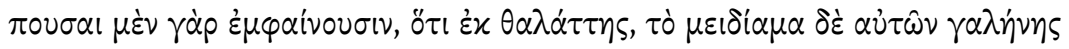

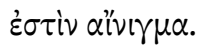

An Aphrodite, made of ivory, tender maidens are hymning in tender myrtle groves. The chorodidaskalos who leads them is skilled in her art, and not yet past her youth; for a certain beauty rests even on her first wrinkle, which, though it brings with it the gravity of age, yet tempers this with what remains of her prime. The type of the goddess is that of 
Aphrodite goddess of Modesty, unclothed and decorous, and the material is ivory, closely joined. However, the goddess is unwilling to seem painted, but she stands out as though one could take hold of her. Do you wish us to pour a libation of discourse on the altar? For of frankincense and cinnamon and myrrh it has enough already, and it seems to me to give out also a fragrance as of Sappho. Accordingly the wisdom of the painting must be praised, first, because the artist, in making the border of precious stones, has used not colors but light to depict them, putting a radiance in them like the pupil in an eye, and, secondly, because he even makes us hear the hymn. For the maidens are singing, are singing, and the chorodidaskalos frowns at one who is off-key, clapping her hands and trying earnestly to bring her into tune ... For as to their garments, they are simple and such as not to impede their movements if they should playfor instance, the close-fitting girdle, the chiton that leaves the arm free, and the way they enjoy treading with naked feet on the tender grass and drawing refreshment from the dew; and the flowered decoration of their garments, and the colors used on them - the way they harmonize the one with the other-are represented with wonderful truth; for painters who fail to make the details consistent with one another do not depict the truth in their paintings. As to the figures of the maidens, if we were to leave the decision regarding them to Paris or any other judge, I believe he would be at a loss how to vote, so close is the rivalry among them in rosy arms and flashing eyes and fair cheeks and in 'honeyed voices', to use the charming expression of Sappho. Eros, tilting up the centre of his bow, lightly strikes the string for them and the bow-string resounds with a full harmony and asserts that it possesses all the notes of a lyre; and swift are the eyes of the god as they recall, I fancy, some particular measure. What, then, is the song they are singing? For indeed something of the subject has been expressed in the painting; they are telling how Aphrodite was born from the sea through an emanation of Uranus. Upon which one of the islands she came ashore they do not yet tell, though doubtless they will name Paphos; but they are singing clearly enough of her birth, for by looking upward they indicate that she is from Heaven (Uranus), and by slightly moving their upturned hands they show that she has come from the sea, and their smile is an intimation of the sea's calm.

The description begins with a double focus: on the ivory statue of Aphrodite and the $\delta 1 \delta \alpha \sigma x \alpha \lambda \circ \varsigma$, leading a chorus of young girls. The description of the statue is an embedded ekphrasis, a description of a work of art within an 
ekphrasis, in this case, the description of a painting. But it is interesting that the description, although constructing an ekphrasis within an ekphrasis, tends to overcome its limits and strives for a realistic effect: the goddess is not

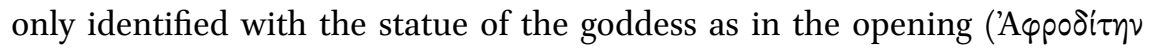
$\dot{\varepsilon} \lambda \varepsilon \varphi \alpha \nu \tau i \nu \eta \nu)$ but also with the painted image of her statue.

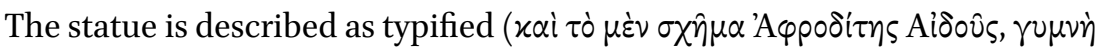

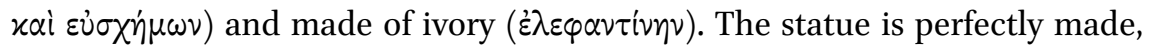

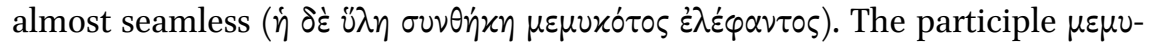
xótos, deriving from the verb $\mu v^{\prime} \omega$ (shut the eyes), introduces a metaphor: the pieces are closely joined together like two eyelids. The metaphor not only emphasizes the closeness and the fact that the two pieces physically belong together but also introduces the importance of eyesight by focusing on the eyes. The intention of the sculptor was to fool the eye, the two pieces appearing like one. But the intention of the sculptor coincides with the intention of the goddess herself whose wish is not to look like a painted image ( $\alpha \lambda \lambda^{\prime} \circ \nu$

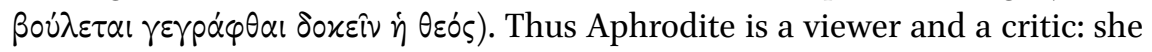
does not want to look as if she were a painting, she wants to look as real-

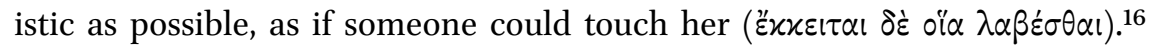
Moreover, the intention of both the goddess and the painter coincides with the one of the writer of the ekphrasis: bringing the scene before the eyes of the reader is the desirable effect of the ekphrasis, as progymnasmata prescribe. ${ }^{17}$

The description of Sappho is the second focus of the ekphrasis. The chorus leader, unlike the dancers, is clearly past her prime although not too old (ovं $\delta^{\prime}$ है $\xi$ (wpos), with the first wrinkles mixed with her past beauty. The description is very precise, visualizing not only the looks but also the overall impression of her stature and physique. The description of her age is also interesting as Sappho has features of both young and old age at the same time, creating a blurring-

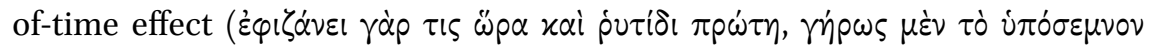

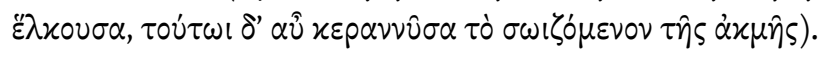

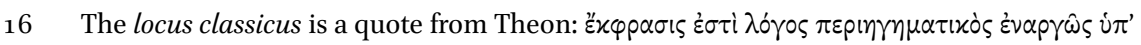

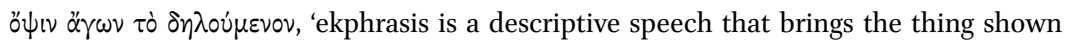
vividly before the eyes' (Prog. p. 118 Spengel = 66 Patillon). For detailed bibliography and discussions on enargeia: Fowler (1991) 26; Goldhill (2007) 3; Bartsch (1989) 9; Webb (2009) Chapter 4. For a theoretical approach on the question of focalization (who sees) see Fowler (1991) 29-31.

17 For rhetorical handbooks on ekphrasis see Webb (2009). For shorter discussions see Bartsch (1989) 7-10; Goldhill (2007) 3-7. 
It is only to be expected that the visual element would be emphasized in the framework of an ekphrasis of a painting. ${ }^{18}$ Moreover, Philostratus describes not only the image but also the act of viewing, the play of light and the effect of the eye capturing this light. ${ }^{19}$ The artist made a frame of precious stones around his painting so that the light reflected in the stones creates a gleaming effect. Referring to the artistry of the painter, Philostratus breaks the realistic effect, reminding his audience that this is really a painting. On the other hand, it highlights its artistry; he is not only a good artist, he is ropós. I suggested earlier that the description of Aphrodite was a case of an embedded ekphrasis. It is my view that Sappho, the second focus of the ekphrasis, is an embedded ekphrasis as well. This time Philostratus describes not a visual artifact, but Sapphic poetry. ${ }^{20}$

In reading the ekphrasis both an act of interpretation and one of emulation become apparent: in order for the $\delta \eta \lambda \circ u \varepsilon \varepsilon v 0 v$ to come before the audience's eyes, a prior knowledge of Sapphic poetry is necessary. Philostratus is describing the grove using Sapphic imagery (frr. 2 and 44 V. in particular) and diction, and he quotes directly from Sappho when calling the chorus girls honey-voiced, 'to use the charming expression of Sappho.'21 The insistence on touch is again

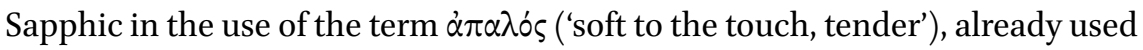
by Sappho in fr. $94 \mathrm{~V}$. His description of a work of art is then two-fold, since he is describing the painting and the poetic work at the same time. It is first the painter himself who tried to imitate Sappho; Philostratus' ekphrasis tries to represent and imitate, or emulate, both. It is noticeable that both Sappho and

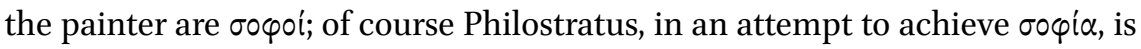
competing with both of them. ${ }^{22}$ Finally, the audience has to be equally wise, a learned audience well versed in visual arts and poetry.

As Shaffer (1998) rightly observes, 'Philostratus' attempt to translate impressions from the pictorial to the literary medium calls attention to the mimetic quality of both and invites the act of interpretation.'23 The wisdom of the paint-

18 See e.g. Webb (2009) 127: 'For what enargeia, and thus ekphrasis, seek to imitate is not so much an object, or scene, or person in itself, but the effect of seeing that thing.'

19 For Goldhill (2007) 2 ekphrasis dramatizes 'the moment of looking as a practice of interpreting, of reading - a way of seeing meaning'.

20 See Shaffer (1998) 313 who discusses Imag. 1.1 (Scamander) and its dialogue with the Homeric poem.

21 Sappho fr. $185 \mathrm{~V}$.

22 For sophos see Goldhill (2007) 2 according to whom ekphrasis 'dramatizes not just an interpretation, but a sophos — an educated wit—interpreting'; and Shaffer (1998) 314.

23 Shaffer $(1998) 304$. 
ing, according to Philostratus, must be praised for two reasons: first, because

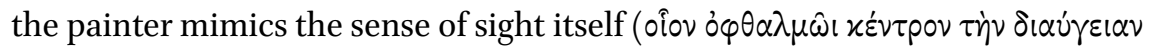

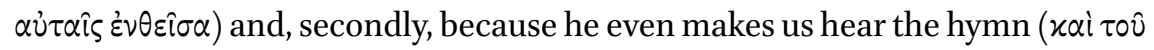
$\left.\ddot{u} \mu \nu \circ v \pi \alpha \rho \dot{\varepsilon} \chi \varepsilon l \dot{\alpha} x \circ v_{\varepsilon} \varepsilon v\right)$. The importance of the visual is then a feature of $\sigma \circ \varphi^{\prime} \alpha$, as is the fusion of all senses, the synaesthetic reception of Sappho. It is evident that Philostratus understands that the painting attempts to engage not only the vision but all other senses as well. ${ }^{24}$ The fact that ekphrasis usually employs all senses is of course well established, since the descriptions of the work of art direct the viewer to perceive them with more senses than sight alone. ${ }^{25}$ As Bartsch rightly observes, interpretation in Philostratus entails seeing and describing more than is actually visible. ${ }^{26}$ What I am suggesting, however, is that Philostratus' appeal to all the senses is also mimicking Sapphic poetry. Apart from the visual, already discussed, there is also an insistence on touch and scent in Philostratus' description: right from the beginning tender girls sing in a tender grove, and later again the emphasis is on the sense of touch when girls feel the soft, moist grass under their bare feet. Scent is again very important: there is an emphasis on the beautiful smell of incense but there are also two interesting points. The first is the idea of discourse as an offering; the ekphrasis is offered to the goddess as incense is:

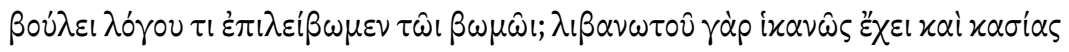

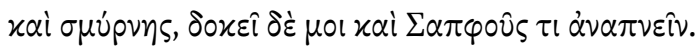

Do you wish us to pour a libation of discourse on the altar? For of frankincense and cinnamon and myrrh it has enough already and it seems to me to give out also a fragrance as of Sappho.

Discourse, usually perceived though hearing, is then fragrant, perceived by smell. Describing Sapphic discourse in synaesthetic terms, Philostratus considers the emphasis on the visual and its combination with other senses, that is,

24 As Shaffer (1998) 308 points out, 'beyond mere visual description, Philostratus attempts to achieve full sensuous reality in the medium of words and even attributes sensations of fragrance and sound to his immediate visual perceptions'.

25 See Webb (2009) 187 who points out that the pictures are meant to elicit a synaesthetic response.

26 Bartsch (1989) 16-17 according to whom 'Philostratus does not restrict himself to a catalogue of details: what he tells his imaginary audience (and us) about the pictures is far from purely descriptive involving both the details actually visible in each picture and those he has brought in from myth, literature, and historiography' (16). 
synaesthesia, as an integral characteristic of Sapphic poetry not only in terms of its perception but also of its reception. Moreover, and most importantly, the fragrance of the ekphrasis, as it were, is nothing but a mimesis of the fragrance of Sapphic discourse. There is then, it seems, a certain scent to a Sapphic song, a scent that the writer of the ekphrasis seems to emulate. Listening to a Sapphic song is, to Philostratus, a synaesthetic experience, where all senses are employed. It is clear, then, I suggest, that Philostratus perceives the fusion of senses as an common feature of Sapphic poetry, one that his audience would recognize as characteristically Sapphic. Hence the interplay of the visual, tactile, and olfactory is recalled to the mind of the audience for the ekphrasis to be closer to its prototype, a more realistic imitation of Sappho's poetry.

I hope to have shown that Philostratus employs a recognizable characteristic of Sapphic poetry as a vehicle for a more realistic ekphrasis. At this point, one more feature of Philostratus' description is worth discussing at some length. At the beginning of the ekphrasis, the portrait of Sappho is clearly that of a chorus teacher leading off a dance of young girls. The network of technical terms refers unmistakably to choral performance. The chorus teacher ( $\dot{\eta} \delta 1 \delta \dot{\alpha} \sigma \kappa \alpha \lambda$ ) $)$ leads

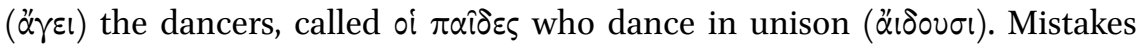
are not tolerated, and the capable leader sets the off-tune girl straight with a 'condescending' look followed by a clap of her hands ( $\dot{v} \pi \circ \beta \lambda \varepsilon \dot{\varepsilon} \pi \varepsilon 1 \tau \eta \dot{\nu} \nu \dot{\alpha} \pi \dot{\alpha} 1 \delta 0 v \sigma \alpha \nu$

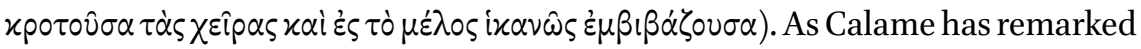
'It is unnecessary to point out the presence of the typically choral semantic features of "leading" and "beginning" in this scene described by Philostratus.' ${ }^{27}$ The harmony of their choreia is represented by 'the way they harmonize the one with the other-are represented with wonderful truth'. In the context of this performance, both steps and voice should be kept in harmony. The harmony of the song is part of Philostratus' visualization, since visual art alone could not have represented such a sequence of motion. Moreover, it is not only the performance but also the content of the song that Philostratus describes: 'what, then, is the song they are singing? For indeed something of the subject has been expressed in the painting.' The subject of the song is represented in both its kinetic and vocal elements. The chorus is singing of the birth of Aphrodite: the painting then is the painting of the performance of a Sapphic song by a chorus of girls in the context of a ritual for Aphrodite. I am not going to suggest that this is a realistic representation of an archaic performance, nor am I using it as evidence to prove that Sappho's songs were composed to be performed. But the testimony of the third-century writer is critical because it indicates that by 
Philostratus' time Sappho's performance is, first, intended to be perceived by all senses and, second, received as choral, in Philostratus' world.

Philostratus is not the only writer who perceives Sappho as a choral poet. In a passage from the Attic Nights, choirs of girls and boys, and lyre players are brought into the dining room to perform songs of Sappho and (pseudo-)Anacreon. ${ }^{28}$

Ac posteaquam introducti pueri puellaeque sunt, iucundum in modum

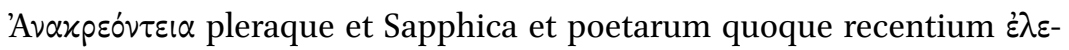
$\gamma \varepsilon \hat{\imath} \alpha$ quaedam erotica dulcia et uenusta cecinerunt.

And when the boys and girls were brought in, they sang in a delightful way several odes of Anacreon and Sappho, as well as some erotic elegies of more recent poets that were sweet and graceful.

The performance itself is not described but it is clear that we are not dealing with a solo performance. I believe that a chorus of girls (puellae) would sing the Sapphic songs and that of the boys (pueri) would then sing Anacreon. Moreover, the fact that the song is sweet is emphasized twice (iucundum, dulcia). Both adjectives can denote taste but are used to describe something perceived with sight and hearing. ${ }^{29}$ The song's perception is, therefore, again described in synaesthetic terms, with both senses blending in. The passage is of course not archaic but it points significantly to the later reception of Anacreontic and Sapphic poetry as choral. The cases of the two poets are very similar, as Dimitrios Yatromanolakis points out. ${ }^{30} \mathrm{He}$ reads the aforementioned passage as reflecting 'the conflation of monodic and choral modes of singing' in second-century AD dinner parties. ${ }^{31}$ I have argued elsewhere in favor of Anacreontic choral performances and I will come back to Anacreon presently, but let me now turn to a last later reference to choral performance of Sappho. ${ }^{32}$

In an epigram in the Palatine Anthology of uncertain date and authorship, Sappho is described as leading a chorus of young girls to the temple of Hera.

28 Aul.Gell. N.A. 19.9.4. Text and translation quoted from Rolf (1968-1978).

29 Iucundus refers to all senses: uerba ad audiendum iucunda, Cic. De Or. 1.49, 213; aqua ... potui iucunda, Plin. Nat. 6.37, 203; iucunde olet, Plin. Nat. 20. 69, 177; conspectus uester est mihi multo iucundissimus, Cic. De Imp. Pomp. 1.1; cantare et psallere iucunde, Suet. Tit. 3 .

30 Yatromanolakis (2007) 213-220.

31 Yatromanolakis $(2007) 84-85$.

32 Ladianou (2005). On Anacreontic performance in sympotic/comastic-ritual setting and its visual representation see Nagy (2007). 
This time their performance is described: the chorus with their soft, whirling footsteps, their sweet voice, their smiling faces, and Sappho as the leader, playing the lyre. Sappho is emphatically described as an $\dot{\xi} \xi \dot{\alpha} p \times 0 v \sigma \alpha$ and as the one who sets up the chorus, most probably the leader, the composer, the lyre player, and the dance teacher: ${ }^{33}$

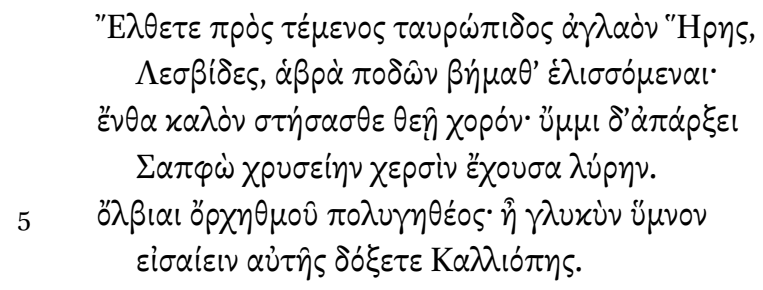

Come to the glorious precinct of bull-faced Hera, women of Lesbos, whirling your delicate footsteps, and set up there the beautiful dance to the goddess; and Sappho will lead you, bearing her golden lyre. Happy you women, in the delightful dancing! Indeed, you will seem to perceive a sweet hymn from Calliope herself.

I am, again, citing the epigram only as an attestation of later Sapphic reception. ${ }^{34}$ The epigram is probably Hellenistic or later but its diction is archaizing, pointing to Sappho and Homeric epic: the performance is therefore presented as archaic. Be that as it may, the poet does describe Sappho as leading a chorus of Lesbian women; we do have the description of footsteps in dance, accompaniment of lyre, and song. Moreover, we have a plethora of terms connected to

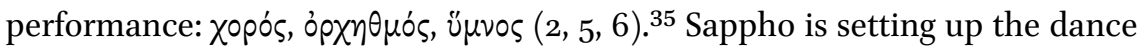
(as a female Stesichoros) and leads in playing the lyre ( $\dot{\alpha} \pi \dot{\alpha} p \xi \varepsilon l, 3)$. The synaesthetic description of a sweet hymn and emphasis on the tenderness ( $\dot{\alpha} \beta \rho \dot{\alpha}, 2)$ of the dancers' footsteps are to be noticed. Moreover, plurality of voices is evident, since not only are Sappho and the chorus probably singing, but the voice of Calliope is also metaphorically joining the dance.

So far, I have suggested that later authors not only perceive the emphasis on the visual and its connection with all other senses as a characteristic of Sapphic poetry but also associate this feature with chorality. Their perception

33 A.P. 9.189. Text and translation quoted from Campbell (1982).

34 For Sappho in Hellenistic epigram see Acosta-Hughes (2010) 82-92. Lardinois (1994) 75 entertains the possibility that the epigram 'reflects an authentic tradition and Sappho sometimes sang her songs in public while her chorus danced'.

For the performative connotations of the term í $\mu \nu \varepsilon i v$ see Peponi (2009) 56 . 
of choral song as synaesthetic is not, however, a first. In the Laws, Plato uses the term choreia to describe the combination of song and dance: $\chi \circ p \varepsilon i \alpha \gamma \varepsilon \mu \eta \nu$

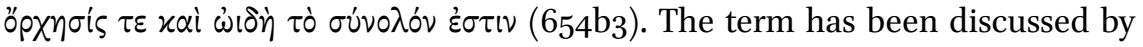
Peponi in the context of the Homeric Hymn to Apollo, with the emphasis on the fact that 'one practicing choreia is principally involved in vocal activity, while kinetic acts visually codify the attitudes and emotions expressed through the uttered words.' ${ }^{36}$ I have also argued elsewhere that, in the context of choreia, hearing and vision are completely fused together. ${ }^{37}$ Moreover, this integration of music, dance, and singing coexist at the levels not only of composition but also of reception. The descriptions of choreia always point not only to hearing and seeing but usually to all senses; the song stages and visualizes its perception not only by hearing but also sight, smell, and touch.

Going back to the epigram, the whirling footsteps ( $\pi \circ \delta \hat{\omega} \nu \beta \eta^{\prime} \mu \alpha \theta^{\prime} \dot{\varepsilon} \lambda \lambda_{l} \sigma \sigma \delta \mu \varepsilon v \alpha l$, 2) of the chorus members are combined with the sound of the lyre and the

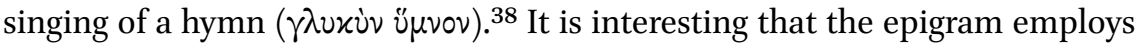

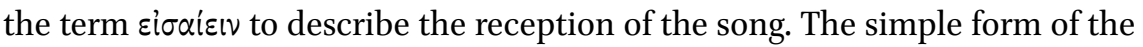
verb is a term that can invariably used to denote both hearing and seeing and I propose that the term is employed here because it carries both meanings. ${ }^{39}$ Using a verb that can reflect both senses, the author exploits a duality already found in Sapphic poetry. ${ }^{40}$ I am therefore proposing that both the Philostratus and the Palatine Anthology passages discussed so far can bear witness to a Sapphic choreia where the kinetic action of the chorus is complementing the Sapphic song.

I have so far suggested that later authors recognized in Sappho's poetry a plurality of voices and blurring of the senses which they associated with chorality. I have also shown that choreia was perceived as a fusion of song and dance already in Plato's time and that fusion of senses was considered to

36 Peponi (2009) 59. Steiner (2011) 319 also points to the 'continued emphasis on the several elements of choreia'.

37 Ladianou (2005) 48.

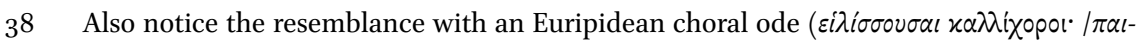

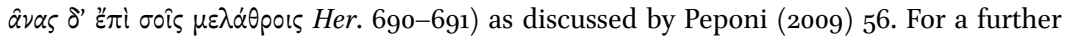
discussion of choreia in dramatic contexts see Steiner (2011).

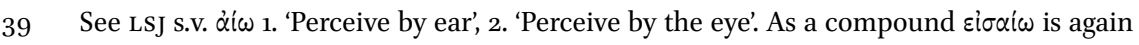
glossed as 1. 'hearing' and 2. 'feeling the effect of'.

40 The term $\alpha \dot{\alpha} \omega$ is used again in the A.P. for the work of a choral poet (Pindar): 7.34.3 $0 \hat{0}$

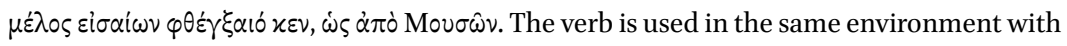

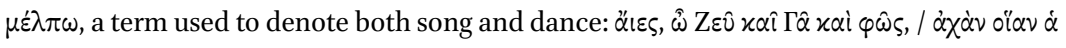

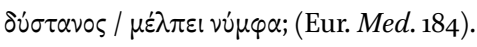


be an integral feature of choreia. In the section which follows I come back to Sappho's fragments, reflecting on the possible interrelation between chorality and synaesthesia.

\section{Looking at the Dance: Sappho and the Chorus}

In the previous section, I discussed later authors' reception of Sappho's poetry, arguing that synaesthesia, the blurring of the senses, is such a primary characteristic of her poetic art that it directly evokes its prototype when imitated. This calls for a final question: if visualization and synaesthesia point to the choral quality of Sappho's poetry, as assumed by the later authors, could theyperhaps-be considered an indication of choral performance? In other words, it will be discussed whether the plurality of voices and multiple sensibilia cannot only be found in her poetry but can also point to a performative reality.

Fragment $2 \mathrm{~V}$. has already been read as choral-performed by a chorus of girls, perhaps in the context of a ritual in honor of a female goddess. ${ }^{41}$ Again the only reference to a chorus ( $\left.\theta \alpha \lambda \lambda^{\prime} \alpha \iota \sigma\right)$ might be found in the problematic end of the fragment, summoning Aphrodite to the festivities. ${ }^{42}$ Although no choral performance is described yet, the emphasis on the fusion of senses points to the performance. ${ }^{43}$ The grove itself is not really inhabited by the chorus and

41 For Sappho's connection to ritual see Nagy (2007). Lardinois (1994), (1996), and (2001) suggests that at least some of Sappho's poetry was composed for choral performance in a ritual setting. See above, n. 19. For fr. 2 v. see especially Lardinois (1994) 78; (1996) 165. Contra Lardinois and others, Yatromanolakis (2003) 53-54 argues that, due to its fragmentary state, fr. 2 cannot be categorized as a cult song or hymn.

42 L.-P. and Campbell print oivoxó $\alpha$ เøov in line 16. Athenaeus (11.9.21) provides a slightly different 'Attic version' reading:

$\dot{\varepsilon} \lambda \theta \dot{\varepsilon}, \mathrm{K} \dot{\pi} \pi \rho \mathrm{l},\langle\ldots\rangle$

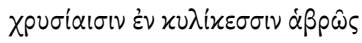

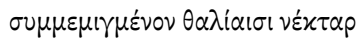

oivoxov̂ $\alpha$

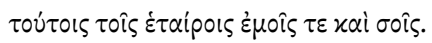

Lardinois (1996) 165 suggests that if this is a part of the poem it can be seen as an indication of the presence of the hetairai. Yatromanolakis (2003) 53 connects the 'Attic version' with the Athenian 'performative transmission of Sappho's songs'. More explicitly, Nagy (2007) 218-219 discusses the two attested closures of the fragment and argues that the 'Attic version' as quoted by Athenaeus points to a sympotic closure and can, therefore, be an indication of its performance by boys or men in Athenian symposia.

In the sense that the relaxation can be followed by a performance. For example see 
still, described through the totality of human senses, it creates human presence and evokes choral performance: apples, altar with incense, murmur of cold water running down the branches, sweet smell of roses, touch, hearing, all fused together as perceived by the senses of the dancers and our own at the same time. It is very probable that the fragment was the model for Philostratus' ekphrasis. Be that as it may, it is safer to point to the fact that Philostratus reconstructs the performance of the Sapphic song through the description she provides in her poetry. In other words, he received the song's reference to the locus amoenus as a reference to the place of the song's performance.

The fragment might have also been in the mind of the rhetor Menander when discussing hymns of invocation $\left(\chi \lambda \eta \tau i x 0^{i}\right){ }^{44}$ Referring to the composition of such hymns by Sappho, Anacreon, and Alcman, he points to the fact that the poets used to describe the places where gods are summoned:45

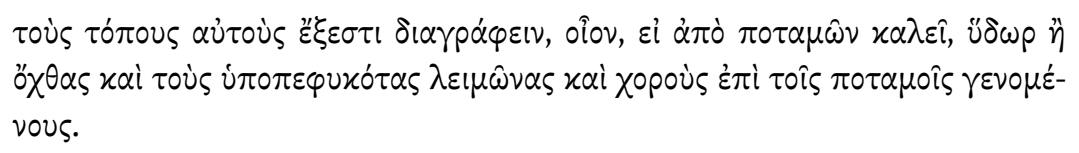

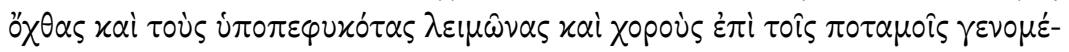
vous.

For they can describe the places themselves: in the case of rivers, the water and banks, the nearby meadows and dances held beside the rivers.

Although there is no positive indication that Menander refers to the fragment at hand, such a description closely resembles the locus amoenus of fr. $2 \mathrm{~V}$., whose beginning points to a cletic hymn. Moreover, the $\theta \alpha \lambda i \alpha i \sigma l$ at the end of the fragment can possibly refer to choral performance, the 'dances' (Xopoús) to which Menander refers. Supposing that the rhetorician had the whole poem at his disposal, it is probable that the final lines of the poem explicitly referred to the performance of a chorus. If that is correct, the external audience of the fragment would also be included in the list of potential audiences, becoming the mirror of the mortal internal audience.

It has already been claimed that both Philostratus and Gellius assume that Sapphic poetry was meant to be chorally performed. Moreover, it is interesting that Gellius brings Sappho and Anacreon together in this passage. His choice

Alcman's second Partheneion (PMGF 3.7-10) where rising from sleep is followed by choral

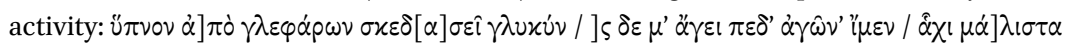

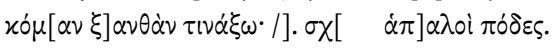

For Menander and ekphrasis see Bartsch (1989) and Webb (2009). For cletic hymns see especially Webb (2009) 156-157, 160-161.

Men. Rhet. п. ₹̇ $\pi \delta$. 334.32-335.3 Spengel = Sappho test. 47 Campbell (his translation). 
is not accidental, since the two cases are similar: they are both considered monodic poets, but their poetry emphasizes the fusion of song with dance. It is also appealing to consider two very similar fragments in which both poets describe symptoms of their old age followed by a desire to dance. Anacreon himself describes the symptoms of his old age in quite a pessimistic tone, but in the Anacreontic tradition the old poet desires to remove the cloak of his old age and join the choreia of the young dancers. ${ }^{46}$ The Tithonus poem offers a good case for comparison. The now complete version of fr. $58 \mathrm{v}$. goes beyond a catalogue of symptoms of old age, attempting to alleviate the realization of ageing with poetry in performance. ${ }^{47}$

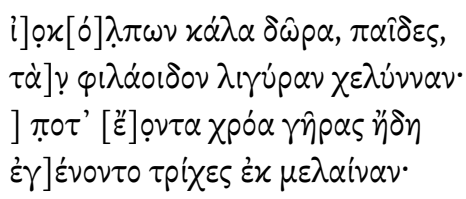

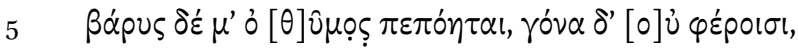

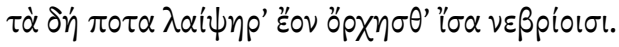

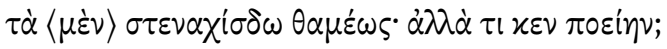

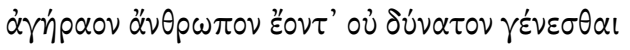

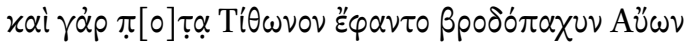

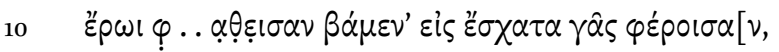

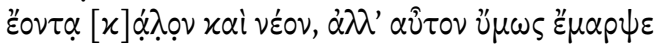

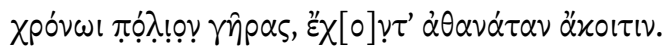

... the violet-rich Muses' fine gifts, children, ... the clear-voiced song-loving lyre. ... skin once was soft is withered now, ... hair has turned white which

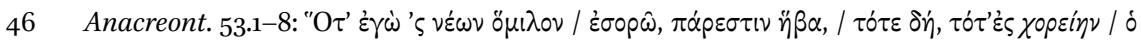

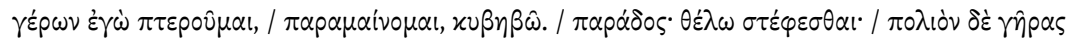

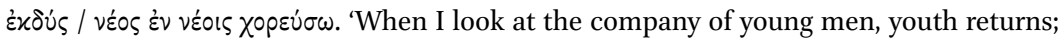
at such times in spite of my age I take wing for the dance. I am totally mad, I am frantic, I want to wear a garland: hand me one! Stripped of my old age, I shall dance, a young among the youths.' (trans. Campbell, with minor adjustments).

47 Text and translation of the 'Tithonus poem' are quoted from Obbink (2009); the translation is also Obbink's. I am sympathetic to the view of those who wish to include 'continuation $2^{\prime}$ as part of the poem or better as a possible version of the poem which survived in a longer and a shorter version, as in Lardinois (2009) 42-45 and 48; Boedeker (2009) 79-81; Nagy (2009) 186 proposes that the longer version would be more appropriate for performance during public events while the shorter for private; Greene (2009) 148, 158-160 aptly demonstrates how the two different endings affect the interpretation of the poem. That said, I choose not to include the continuation since it does not affect my discussion. 
once was black; my heart has been weighted down, my knees which once were swift for dance like young fawns fail me. How often I lament these things. But what can you do? No being that is human can escape old age. For people used to think that Dawn with rosy arms ... Tithonus fine and young to the edges of the earth; yet still grey old age in time did seize him, though he had a deathless wife.

The poetic 'I' addresses a chorus of young girls ( $\pi \alpha \hat{\imath} \delta \varepsilon \varsigma$ ), asking them to fetch a lyre under the tunes of which a performance is going to take place. There is no reference to actual dancing but the reference to the lyre cannot but lead to a performative context. The reference to a past choreia does occur later in the

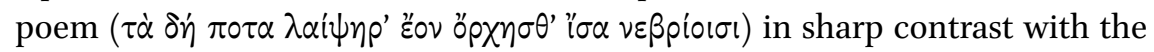
immobile limbs of the old poet. Sappho bemoans the fact that her poetic ability is reduced both because her thymos is now growing heavier but also because she cannot anymore be a part of a performing chorus. In this poem, then, the poet considers dancing to be an integral part of her own poetic performance. ${ }^{48}$

Moreover, the way Sappho stages space and time is very interesting. ${ }^{49}$ In talking about her aging, she does not merely list the symptoms of old age, as Anacreon does in $P M G 395 .{ }^{50}$ In Sappho old and young age are described at the same time, as the poet juxtaposes past and present. The poem is structured on antithesis: soft skin vs. wrinkles, white hair vs. black, light vs. heavy heart, nimble knees vs. stiff ones. The effect is then different from mere symptomatology,

48 Compare also Alcm. PMGF 26

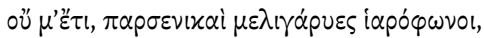

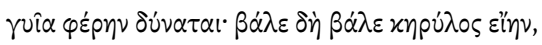

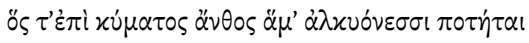

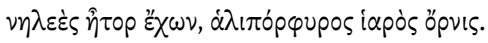

'No longer, honey toned, strong-voiced girls, can my limbs carry me. If only I were a cerylus, who lives along with the halcyons over the flower of the wave with resolute heart, strong, sea-blue bird' (trans. Campbell).

For a connection of the two fragments see also Lardinois (1994) 67 .

For an excellent discussion of temporal markers see Stehle (2009).

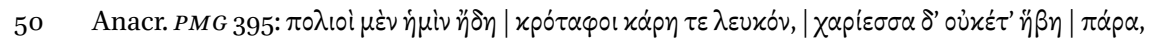
Ү

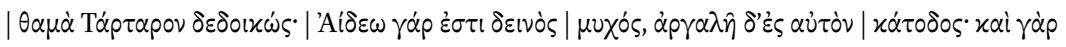

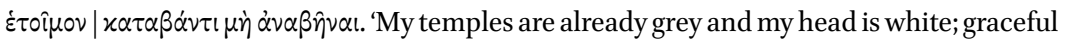
youth is no more with me, my teeth are old, and no long span of sweet life remains now. And so I often weep in fear of Tartarus: for the recess of Hades is grim, and the road down to it grievous; and it is certain that he who goes down does not come up again' (trans. Campbell). 
since her old body and young body are described at the same time, creating a visual —almost cinematic — effect: she is seen as both the old, wrinkly, whitehaired, immobile woman and the young, soft skinned, black-haired dancer. She is, in essence, cheating time. As in fr. $94 \mathrm{~V}$., time is then fluid, an effect visualized in performance. As the chorus of young girls dances, Sappho's past and present are both staged: they can still dance as fawns and by saying these words the 'young' Sappho can, again, dance. Differently from Tithonus' case, then, poetic immortality and eternal youth can be achieved in performance.

Sappho and Anacreon both provide us with poems dealing with old age and choreia. In both cases, literary tradition and testimonia attest to the fact that the two poets are considered to be choral; ${ }^{51}$ I would argue that this has to do with their reception as choral poets and with their highly visual poetic art. In the same context, representations of Sappho in vase paintings such as the red figure hydria from the Archaeological Museum in Athens insist on representing Sappho with a lyre, garlands, and scrolls of poetry flanked with female companions. ${ }^{52}$ It must be noted that no vase painting with a named Sappho leading a chorus has survived; but if in Sappho and Anacreon the idea of chorality is already in the poem itself, the poem creating and recreating its performance, then it is not surprising that artists tried to represent by means of their art that which Sappho represented in hers: the visualization of chorality.

Ruth Webb has argued that 'the rhetorical manuals reveal to the modern reader the rich network of ideas and assumptions that underlay the composition and reception of ancient texts. ${ }^{53}$ Hermogenes, then, emphasizing the pleasure via the senses as an effect of Sapphic poetry and Menander regarding choral dances as the sine qua non of a cletic hymn can shed some light on the assumptions of the ancient reader and the reception of the Sapphic text. On that note, I would further suggest that the insistence of later allusions to choral performances of Sapphic poetry (Gellius, Philostratus) can be taken as a possible indication of actual Sapphic chorality. This insistence, I submit, in using the vocabulary and imagery of choral singing and dancing may lead one to suspect that these were thought as indispensable characteristics of the Sapphic poetic identity. But more importantly, I hope I have shown that in Sapphic poetry imagery and the visualization point to a blurring of boundaries that can be better understood in a performative reality of choreia. In Sappho's poetry

$5^{1} \quad$ Yatromanolakis (2007) 64 and 85 points out that Sappho and Anacreon are the two most popular poets in vase paintings, where they are represented at the time of performance. On vase paintings and Sapphic performance see Yatromanolakis (2001) and (2007). More to the point Nagy (2007) 233-235, 226, 230, 243, who brings Sappho and Anacreon together.

Webb (2009) 4-5. 
the fixity and stability of a 'text' are undone by performance. For every time it is performed, the time and spatial markers of the poem (here-there, now-then) change. ${ }^{54}$ If the poem itself enforces time-, space- and voice-shifts, permitting fluidity and a blurring of boundaries, performance goes one step further. Space and time become even more fluid since 'here' and 'now' change with any given performance and the act of saying the words is not an attempt to fix the moment, but the acceptance of the impossibility of doing so.

\section{Works Cited}

Acosta-Hughes, B. (2010). Arion's Lyre: Archaic Lyric into Hellenistic Poetry. Princeton.

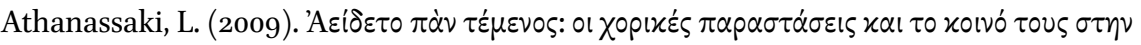

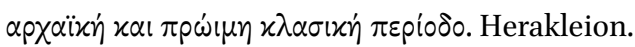

Bakker, E. (2009). 'Homer, Odysseus and the narratology of performance' in J. Grethlein and A. Rengakos (eds), Narratology and Interpretation: The Content of Narrative Form in Ancient Literature. Berlin: 117-136.

Bartsch, S. (1989). Decoding the Ancient Novel: the Reader and the Role of Description in Heliodorus and Achilles Tatius. Princeton.

Bartsch, S. and Elsner, J. (eds) (2007). CPh 102.1: Special Issue on Ekphrasis.

Burnett, A.P. (1983). Three Archaic Poets: Archilochus, Alcaeus, Sappho. London.

Calame, C. (1996). 'Sappho's group: an initiation into womanhood' in Greene (ed.) (1996): 113-124.

(2001). Choruses of Young Women in Ancient Greece: Their Morphology, Religious Role, and Social Function. Trans. D. Collins and J. Orion. Lanham, MD.

Campbell, D.A. (1982). Greek Lyric, I: Sappho and Alcaeus. Cambridge, MA.

Carey, C. (2009). 'Genre, occasion and performance' in F. Budelmann (ed.), The Cambridge Companion to Greek Lyric. Cambridge: $21-38$.

Dubel, S. (2009). 'Colour in Philostratus' Imagines' in E. Bowie and J. Elsner (eds), Philostratus. Cambridge: 309-321.

Fairbanks, A. (1931). Philostratus. Imagines. Cambridge, MA.

Fowler, D.P. (1991). 'Narrate and describe: The problem of ekphrasis'. JRS 81: 25-35.

Gentili, B. (1988). Poetry and its Public in Ancient Greece:From Homer to the Fifth Century. Trans. A.T. Cole. Baltimore.

54 See Bakker (2009) 122-125 who coins the term 'projected indexicality'. According to him, when statements containing deictic references are meant to be performed (and reperformed) their inbuilt 'hereness' or 'nowness' are projected. For the polysemy of deixis in the performance and reperformance of Pindar and Bacchylides see Athanassaki (2009). 
Goldhill, S. (1994). 'The naïve and knowing eye: Ecphrasis and the culture of viewing in the Hellenistic world' in S. Goldhill and R. Osborne (eds), Art and Text in Ancient Greek Culture. Cambridge: 197-223. (2007). 'What is ekphrasis for?' in Bartsch and Elsner (eds) (2007): 1-19.

Greene, E. (2009) 'Sappho 58. Philosophical reflections on death and aging' in Greene and Skinner (eds) (2009): 147-161.

Greene, E. (ed.) (1996). Reading Sappho: Contemporary Approaches. Berkeley.

Greene, E. and Skinner, M.B. (eds) (2009). The New Sappho on Old Age: Textual and Philosophical Issues. Washington, DC.

Hallett, J. (1979). 'Sappho and her social context: Sense and sensuality'. Signs 4:447464.

Ladianou, K. (2005). 'The poetics of choreia: Imitation and dance in the Anacreontea'. QUCC 80: 47-60.

Lardinois, A. (1994). 'Subject and circumstance in Sappho's poetry'. TA PA 124: 57-84.

- (1996). 'Who sang Sappho's songs?' in Greene (ed.) (1996): 150-172.

(2001). 'Keening Sappho' in A. Lardinois and L. McClure (eds), Making Silence Speak: Women's Voices in Greek Literature and Society. Princeton: 75-92.

Leach, E.W. (1988). The Rhetoric of Space: Literary and Artistic Representations of Landscape in Republican and Augustan Rome. Princeton.

Nagy, G. (2007). 'Did Sappho and Alcaeus ever meet?' in A. Bierl, R. Lämmle and K. Wesselmann (eds), Wege zu einer mythisch-rituellen Poetik bei der Grieschen. MythosEikonPoesis 1.1: 211-269.

- (2009). "The "new Sappho" reconsidered in the light of the Athenian reception of Sappho' in Greene and Skinner (eds) (2009): 176-199.

Obbink, D. (2009). 'Sappho fragments $5^{8-59}$. Text, apparatus criticus, and translation' in Greene and Skinner (eds) (2009): 7-16.

Parker, H. (1993). 'Sappho schoolmistress'. TAPA 123: 309-351.

Peponi, A.E. (2009). 'Choreia and aesthetics in the Homeric Hymn to Apollo: The performance of the Delian Maidens (lines 156-164)'. cA 28.1: 39-70.

Rolfe, J.C. (1968-1978). The Attic Nights of Aulus Gellius. Cambridge, MA.

Shaffer, D. (1998). 'Ekphrasis and the rhetoric of viewing in Philostratus' imaginary museum'. Philosophy \& Rhetoric 31.4: 303-316.

Stehle, E. (2009). “'Once” and "now." Temporal markers and Sappho's self-representation' in Greene and Skinner (eds) (2009): 118-130.

Steiner, D. (2011). 'Dancing with the stars: Choreia in the third stasimon of Euripides' Helen'. CPh 106.4: 299-323.

Webb, R. (2009). Ekphrasis, Imagination and Persuasion in Ancient Rhetorical Theory and Practice. Farnham.

Winkler, J. (1990). The Constraints of Desire. The Anthropology of Sex and Gender in Ancient Greece. New York. 
Whitmarsh, T. (2013). Beyond the Second Sophistic: Adventures in Greek Postclassicism. Berkeley.

Yatromanolakis, D. (2001). 'Visualizing poetry: An early representation of Sappho'. CPh 96.2: $159-168$.

(2003). 'Ritual poetics in archaic Lesbos: Contextualizing genre in Sappho' in D. Yatromanolakis and P. Roilos (eds), Towards a Ritual Poetics. Athens: 43-59. (2007). Sappho in the Making: The Early Reception. Cambridge, MA. 